\title{
Metabolic Acidosis Stimulates Muscle Protein Degradation by Activating the Adenosine Triphosphate-dependent Pathway Involving Ubiquitin and Proteasomes
}

\author{
William E. Mitch, Ruth Medina, * Stefan Grieber, Robert C. May, Brian K. England, S. Russ Price, \\ James L. Bailey, and Alfred L. Goldberg* \\ Renal Division, Emory University School of Medicine, Atlanta, Georgia 30322; and * Department of Cellular and Molecular Physiology, \\ Harvard Medical School, Boston, Massachusetts 02115
}

\begin{abstract}
Metabolic acidosis often leads to loss of body protein due mainly to accelerated protein breakdown in muscle. To identify which proteolytic pathway is activated, we measured protein degradation in incubated epitrochlearis muscles from acidotic ( $\mathrm{NH}_{4} \mathrm{Cl}$-treated) and pair-fed rats under conditions that block different proteolytic systems. Inhibiting lysosomal and calcium-activated proteases did not reduce the acidosis-induced increase in muscle proteolysis. However, when ATP production was also blocked, proteolysis fell to the same low level in muscles of acidotic and control rats. Acidosis, therefore, stimulates selectively an ATP-dependent, nonlysosomal, proteolytic process.

We also examined whether the activated pathway involves ubiquitin and proteasomes (multicatalytic proteinases). Acidosis was associated with a 2.5 - to 4-fold increase in ubiquitin mRNA in muscle. There was no increase in muscle heat shock protein 70 mRNA or in kidney ubiquitin mRNA, suggesting specificity of the response. Ubiquitin $\mathrm{mRNA}$ in muscle returned to control levels within $24 \mathrm{~h}$ after cessation of acidosis. mRNA for subunits of the proteasome ( $\mathrm{C2}$ and $\mathrm{C3})$ in muscle were also increased 4-fold and 2.5-fold, respectively, with acidosis; mRNA for cathepsin B did not change. These results are consistent with, but do not prove that acidosis stimulates muscle proteolysis by activating the ATP-ubiquitin-proteasomedependent, proteolytic pathway. (J. Clin. Invest. 1994. 93: 2127-2133.) Key words: glyceraldehyde-3-phosphate dehydrogenase $\bullet$ lysosomes $\bullet$ messenger RNA $\bullet$ proteases $\bullet$ proteolysis
\end{abstract}

\section{Introduction}

In humans, conditions associated with metabolic acidosis are often characterized by negative nitrogen balance and loss of body protein. For example, the poor growth of children with renal tubular acidosis can be sharply improved by providing them with supplements of sodium bicarbonate (1). In normal

A preliminary report of this study appeared in abstract form (1991. FASEB J. 5:A922).

Address correspondence to Dr. William E. Mitch, Renal Division, Emory University School of Medicine, 1364 Clifton Road, Atlanta, GA 30322.

Received for publication 23 August 1993 and in revised form 31 December 1993.

J. Clin. Invest.

(c) The American Society for Clinical Investigation, Inc. $0021-9738 / 94 / 05 / 2127 / 07 \$ 2.00$

Volume 93, May 1994, 2127-2133 adults, metabolic acidosis stimulates intracellular protein degradation and oxidation of branched-chain amino acids (2). Moreover, the nitrogen balance of patients with chronic renal failure improves when they are given sodium bicarbonate (3).

Evidence from experimental animals shows that metabolic acidosis depresses growth and increases urinary excretion of nitrogen and 3-methylhistidine, suggesting increased protein catabolism in skeletal muscle $(4,5)$. By using the constant infusion of $\mathrm{L}-\left[1-{ }^{14} \mathrm{C}\right]$ leucine technique in intact, awake rats, May et al. (6) recently showed that metabolic acidosis stimulates overall protein degradation and leucine oxidation in vivo. In related experiments, May et al. (4) demonstrated that protein degradation increases in muscles of fed rats made acidotic by adding acid to their food, while protein synthesis does not change. Similarly in cultured myocytes, acidification of the media stimulates overall protein degradation (7).

Like other mammalian cells, skeletal muscle contains at least four intracellular proteolytic systems which appear to serve distinct functions (8). The major cytosolic pathway is a soluble, multienzyme system that requires ATP and the polypeptide cofactor, ubiquitin (9). In this system, proteins to be degraded are covalently linked to multiple ubiquitin chains which marks them for rapid hydrolysis by the $26 \mathrm{~S}$ ( $1,500 \mathrm{kD})$ proteasome complex (also called the "multicatalytic proteinase") (9-11). The proteolytic core of this multienzyme complex is the $20 \mathrm{~S}(600 \mathrm{kD})$ proteasome particle which contains $12-15$ distinct subunits $(11,12)$. This pathway catalyzes the selective degradation of abnormal proteins and many shortlived regulatory polypeptides $(9,13)$. Recent data indicate that in response to denervation or fasting, this system is responsible for the enhanced degradation of most proteins in muscle, especially myofibrillar components $(14,15)$.

Endocytosed proteins and most membrane components are degraded by another proteolytic system, acidic proteases in lysosomes, but this organelle also appears to be important in degrading certain cytosolic proteins, especially in catabolic states (16). In most mammalian cells, protein breakdown increases up to twofold by this autophagic pathway upon deprivation of insulin or glucose (16). In muscles, as in other tissues, this lysosomal process can be sharply reduced by adding insulin and amino acids, and can be blocked selectively either by adding weak bases which inhibit lysosomal acidification or by adding inhibitors of lysosomal proteases $(14,17,18)$.

A third proteolytic system present in muscle proteins involves the calcium-activated proteases (calpains I and II). These enzymes are activated by treatments that raise intracellular calcium $(17,18)$ and appear important in the proteolysis occurring in muscular dystrophy (19) or after muscle damage (17). Finally, mammalian cells contain a degradation system not involving lysosomes that does not require calcium nor $\operatorname{ATP}(8,20)$. 
The relative importance of these four processes for the degradation of different proteins in muscle is unclear in normal conditions and in states associated with accelerated proteolysis. For example, it is not known whether the enhanced muscle proteolysis stimulated by metabolic acidosis is due to activation of all proteolytic pathways or of a specific pathway. The present experiments were directed at identifying which proteolytic system in skeletal muscle is stimulated by metabolic acidosis. Since skeletal muscle plays a critical role in the response to acidosis and since other conditions that stimulate muscle proteolysis (e.g., denervation and fasting) seem to activate the ATP-dependent proteolytic pathway in muscle $(8,15)$, we concentrated on evaluating the ATP-ubiquitin-proteasome system. Our results suggest that in muscle of acidotic rats, this proteolytic pathway is activated, including up-regulating the abundance of mRNAs encoding protein components of this degradative system.

\section{Methods}

Male Sprague-Dawley rats weighing 125-150 g were purchased from Harlan (Indianapolis, IN) and fed $24 \%$ protein rat laboratory diet for at least $3 \mathrm{~d}$ before beginning a gavage-feeding protocol $(4,6)$ that induces metabolic acidosis while ensuring an equivalent intake of protein ( 1.7 $\mathrm{g} / \mathrm{d})$, energy $(49.9 \mathrm{kcal} / \mathrm{d})$, vitamins, and minerals. The protocol avoids the confounding effects of starvation on muscle protein turnover (15). For $5 \mathrm{~d}, 4 \mathrm{mmol}$ of ammonium chloride $\left(\mathrm{NH}_{4} \mathrm{Cl}\right)$ per $100 \mathrm{~g}$ of body wt/day were added to the gavage feeding of acidotic rats and $0.25 \mathrm{M} \mathrm{NH}_{4} \mathrm{Cl}$ was added to their drinking water; control rats were gavage-fed the same diet but no $\mathrm{NH}_{4} \mathrm{Cl}$ and drank tap water. In our earlier report, we found that changes in muscle protein turnover were caused by acidosis and not by feeding ammonium (4). We also measured $(21)$ the systolic blood pressure and heart rate by the tail-cuff method (IITC Life Science Instrument, Woodland Hills, CA) before and at the end of this protocol which induces acidosis.

Initial experiments evaluated the influence of lysosomal and calcium-activated proteases by comparing total protein degradation in one muscle incubated in a standard media and the contralateral muscle incubated with inhibitors of lysosomal and calcium-activated proteases $(22,23)$. In these experiments, epitrochlearis muscles from acidotic and control rats were dissected and one was fixed at resting length by pins placed through the proximal aponeurosis and distal tendons into a plastic support. Individual muscles were preincubated for $1 \mathrm{~h}$ at $37^{\circ} \mathrm{C}$ in $3 \mathrm{ml}$ of $\mathrm{KRB}$ ( $\mathrm{pH} \mathrm{7.4)} \mathrm{containing} 10 \mathrm{mM}$ glucose and $0.5 \mathrm{mM}$ cycloheximide. This concentration of cycloheximide blocks protein synthesis $>95 \%$ (22) and was added to block reutilization of tyrosine released from degradation of muscle proteins. Acidosis does not change protein synthesis in muscle (4). Lysosomal and calcium-dependent proteases were blocked in the contralateral muscle maintained at resting length by preincubation in $3 \mathrm{ml}$ of calcium-free $\mathrm{KRB}(\mathrm{pH} \mathrm{7.4)}$ prepared containing $10 \mathrm{mM}$ glucose, $1 \mathrm{mU}$ human insulin (plus $0.1 \%$ bovine albumin to prevent insulin binding to glass), branched-chain amino acids ( $170 \mu \mathrm{M}$ leucine, $200 \mathrm{mM}$ valine, $100 \mathrm{mM}$ isoleucine) and $0.5 \mathrm{mM}$ cycloheximide with inhibitors. Insulin, branched-chain amino acids and $10 \mathrm{mM}$ methylamine were added to inhibit lysosomal acidification and function $(20,22-24)$, while maintaining muscles at resting length, deleting calcium from the media and adding $50 \mu \mathrm{M}$ trans-epoxysuccinyl-L-leucylamido-(4-guanidino butane) (E-64), ${ }^{1}$ a potent inhibitor of the calpains as well as the lysosomal proteases cathepsins $B, H$, and $L(23,25)$, was used to prevent activation of cal-

1. Abbreviations used in this paper: E64, trans-epoxysuccinyl-L-leucylamido-(4-guanidino)butane; GAPDH, glyceraldehyde-3-phosphate dehydrogenase; HSP70, heat shock protein 70; SSPE, 0.15 M Nacl, $0.01 \mathrm{M} \mathrm{NaH}_{2} \mathrm{PO}_{4}, 1 \mathrm{M}$ EDTA. cium-dependent proteases. After $1 \mathrm{~h}$ of preincubation, each muscle was transferred to a flask containing fresh media and incubated at $37^{\circ} \mathrm{C}$ for a 2-h experimental period. All flasks were gassed with $95 \% \mathrm{O}_{2} / 5 \% \mathrm{CO}_{2}$ for $3 \mathrm{~min}$ at the beginning of both the preincubation and experimental periods. At the end of the experimental period, media samples were collected, and TCA ( final concentration, $10 \%$ ) was added to precipitate protein. The free tyrosine released into the media was measured to determine the overall rate of protein degradation $(14,17,22,23)$.

ATP-dependent proteolysis. To determine the contribution of the nonlysosomal, ATP-dependent proteolytic process to the increased muscle protein degradation associated with metabolic acidosis, muscles were fixed at resting length and initially incubated under the conditions described above to block both the lysosomal and calcium-dependent proteolytic systems. In earlier experiments (4) we reported that acidosis does not reduce the ATP content of incubated muscles, and in preliminary experiments, we found that adding insulin, glucose, amino acids, and methylamine and E-64 does not change the level of ATP in incubated muscles. To measure the ATP-dependent process, the epitrochlearis muscle from one forelimb was depleted of ATP by preincubating for $1 \mathrm{~h}$ and then incubating it with $5 \mathrm{mM}$ 2-deoxyglucose and 0.5 $\mathrm{mM}$ dinitrophenol. The media consisted of calcium-free KRB with insulin, branched-chain amino acids, methylamine and E-64 but no glucose. Preliminary experiments showed that the ATP content of muscles incubated under these conditions decreased by $>95 \%$. The rate of protein degradation in the ATP-depleted muscle was compared to the rate in the contralateral muscle incubated in the same media but with $10 \mathrm{mM}$ glucose and no 2-deoxyglucose or dinitrophenol. The difference in the rates of proteolysis between the muscles was taken to represent the ATP-dependent component.

$m R N A$ levels. To obtain a sufficient quantity of mRNA to analyze differences in levels of specific mRNA transcripts, we studied the gastrocnemius muscle which, like epitrochlearis, is a mixed fiber muscle (26). Individual, intact muscles were isolated and weighed, and their content of protein (27) and DNA (28) was measured. The total RNA content was determined by homogenizing $100-150 \mathrm{mg}$ of muscle in 1.5 ml TriReagent (Molecular Research Center, Cincinnati, $\mathrm{OH}$ ) and centrifuging at $14,000 \mathrm{~g}$ for $5 \mathrm{~min}$. RNA in the clear supernatant was isolated according to the manufacturer's protocol and dissolved in Formazol (Molecular Research Center) before absorbances at 260 and 280 nm were measured. Total RNA was separated in a $1 \%$ agarose/formaldehyde gel and transferred to a Nytran hybridization membrane (Schleicher \& Schuell, Inc., Keene, NH).

After cross-linking with UV-irradiation, RNA was stained with methylene blue (29). 18S and 28S ribosomal RNA was quantified by analysis of the density of the ribosomal RNA bands. Subsequently, the membrane was hybridized at $42^{\circ} \mathrm{C}$ overnight in $5 \times \mathrm{SSC}, 0.1 \%$ SDS, $50 \%$ formamide, $5 \times$ Denhardt's solution, $10 \%$ polyethylene glycol containing $100 \mu \mathrm{g} / \mathrm{ml}$ denatured herring testis DNA with a glyceraldehyde-3-phosphate dehydrogenase (GAPDH) cDNA probe (30); the GAPDH cDNA was labelled with $\left[{ }^{32} \mathrm{P}\right] \mathrm{dCTP}(31)$. After hybridization, the membrane was washed once in $2 \times \mathrm{SSC} / 0.5 \% \mathrm{SDS}$ at $42^{\circ} \mathrm{C}$ for $20 \mathrm{~min}$ and twice in $0.2 \times \mathrm{SSC} / 0.5 \% \mathrm{SDS}$ at $65^{\circ} \mathrm{C}$ for $20 \mathrm{~min}$ each. GAPDH mRNA abundance was quantified by analysis of the density of the autoradiographic signal; the intensity of the GAPDH mRNA was tested to determine if it is proportional to the duration of exposure of the film.

For Northern blotting, total RNA was isolated by homogenizing tissues in guanidinium isothiocyanate and using the guanidinium isothiocyanate/cesium chloride method (29). RNA ( $10 \mu \mathrm{g}$ ) was separated by electrophoresis in a $1 \%$ agarose gel containing $0.2 \mathrm{M}$ formaldehyde and transferred to a nylon membrane (Gene Screen, DupontNEN Research Products, Boston, MA). RNA was crosslinked to the membrane by UV-irradiation and the membranes were hybridized at $65^{\circ} \mathrm{C}$ with ${ }^{32} \mathrm{P}$-labeled cDNA probes prepared by the random-primer method $(29,31)$. The hybridization buffer was $1 \times$ Denhardt's solution, $0.05 \mathrm{M}$ Tris- $\mathrm{HCl}(\mathrm{pH} 7.5), 1 \mathrm{M} \mathrm{NaCl}, 0.1 \%$ sodium pyrophosphate, $1 \%$ SDS containing $100 \mu \mathrm{g} / \mathrm{ml}$ denatured salmon sperm DNA. After hybridization, the filters were washed in $0.5 \times \mathrm{SSC} / 1 \% \mathrm{SDS}$ at 
$42^{\circ} \mathrm{C}$ or $65^{\circ} \mathrm{C}$. Filters were then exposed to XAR-2 films (Eastman Kodak Co., Rochester, NY) at $-70^{\circ} \mathrm{C}$ for autoradiography.

To evaluate the level of mRNA for cathepsin, we used a 513-bp Hind III/EcoR I restriction fragment of a human cathepsin B cDNA (bases 665-1177; kindly supplied by Dr. D. Steiner, University of Chicago) that exhibits $82.5 \%$ identity to the corresponding region of a rodent cathepsin B cDNA sequence (32). The fragment was subcloned into pGEM3zf (Promega Corp., Madison, WI) and the 513-base cRNA probe was synthesized in the presence of $\left[\alpha-{ }^{32} \mathrm{P}\right] \mathrm{CTP}(3,000$ $\mathrm{Ci} / \mathrm{mmol}$ ) using T7 RNA polymerase. The RNA blot was prehybridized at $50^{\circ} \mathrm{C}$ in $5 \times$ Denhardt's solution, $1 \%$ SDS, $5 \times 0.15 \mathrm{M} \mathrm{NaCl}$, $0.01 \mathrm{M} \mathrm{NaH}_{2} \mathrm{PO}_{4}, 1 \mathrm{M}$ EDTA (SSPE), 50\% deionized formamide, $10 \%$ polyethylene glycol containing $50 \mu \mathrm{g} / \mathrm{ml}$ denatured herring testis DNA. RNA was then hybridized overnight with $55 \mathrm{ng}$ of cRNA probe $\left(7.7 \times 10^{8} \mathrm{dpm} / \mu \mathrm{g}\right.$ RNA $)$ in $2.5 \times$ Denhardt's solution, $1 \%$ SDS, 5 $\times$ SSPE, $50 \%$ formamide, $10 \%$ polyethylene glycol containing $50 \mu \mathrm{g} /$ $\mathrm{ml}$ denatured herring sperm DNA. The blot was exposed for $7 \mathrm{~d}$ at $-70^{\circ} \mathrm{C}$ with intensifying screens after one wash with $2 \times$ SSPE, $0.1 \%$ SDS at $50^{\circ} \mathrm{C}$ and two successive washes with $0.2 \times$ SSPE, $0.1 \%$ SDS at $60^{\circ} \mathrm{C}$.

Materials and reagents. The ubiquitin cDNA was kindly provided by Dr. M. Schlesinger (Washington University School of Medicine) (33). The cDNA probe for heat shock protein 70 (HSP70) was provided by Dr. R. Voellmy (University of Miami School of Medicine); cDNAs for subunits of the proteasome $(34,35)$ were generously provided by Dr. K. Tanaka (Tokushima University, Japan). E-64 was a generous gift of Dr. K. Hanada (Taisho Pharmaceuticals, Tokyo, Japan).

Radionucleotides were purchased from New England Nuclear (Boston, MA), guanidinium isothiocyanate from Fluka (Ronkonkoma, NY), cesium chloride from BRL (Bethesda, MD) and human recombinant insulin from Novo Nordisk Pharmaceuticals (Princeton, NJ). All other chemicals were obtained from Sigma Chemical Co. (St. Louis, MO) and were of reagent grade.

Calculations. Values are presented as mean \pm SEM. When muscles from individual rats were compared, a paired Students's $t$ test was used while an unpaired $t$ test was used to compare blood $\mathrm{pH}$ and bicarbonate or muscle biochemical values. For comparing mRNA levels, values in muscles of groups of rats were averaged and an unpaired $t$ test was used. As a limit for significance, $P<0.05$ was assumed.

\section{Results}

The $\mathrm{pH}$ and $\mathrm{PCO}_{2}$ in aortic blood was measured and the serum bicarbonate was calculated to determine the degree of metabolic acidosis and avoid the confounding influence arising from any anesthesia-related, respiratory acidosis (36). Rats treated with $\mathrm{NH}_{4} \mathrm{Cl}$ (aortic blood, serum bicarbonate of acidotic rats was $11 \pm 1$ compared to $24 \pm 1 \mathrm{mq} /$ liter in control rats; $n=11$ in each group, $P<0.01$ by unpaired $t$ test ) had a similar degree of metabolic acidosis as we found earlier $(4,6,37)$. Before the acid load, the mean values of the systolic blood pressure and heart rate of six rats were measured by the tail cuff method ( 21 ) were $151 \pm 4 \mathrm{mmHg}$ and $460 \pm 17$ beats/min; after $5 \mathrm{~d}$ of gavage feeding $\mathrm{NH}_{4} \mathrm{Cl}$, the mean value was $167 \pm 6$ and $465 \pm 21$, respectively ( $P=$ NS, by paired $t$ test $)$.

Changes in protein degradation with acidosis. The results in Table I confirm that metabolic acidosis stimulates protein degradation in isolated epitrochlearis muscles (4). We have found (4) that insulin, which suppresses autophagic vacuole formation $(14,16)$, decreased the rate of protein degradation in muscles from control and acidotic rats by the same amount (over a wide range of insulin concentrations) but did not reduce the component stimulated by acidosis. Also adding an inhibitor of thiol proteases, E-64, did not significantly changed the rate of protein degradation in muscles of control or acidotic rats (4). The present experiments provide further evidence that inhibiting lysosomal and calcium-dependent proteases does not block the component of protein degradation which is stimulated by acidosis (Table I). In muscles of control rats, inhibition of these proteolytic systems reduced protein degradation by $19 \%$ and by $18 \%$ in muscles of acidotic rats.

In contrast, the increase in protein degradation in acidotic muscles was eliminated when these muscles were also depleted of ATP by treatment with inhibitors of respiration and glycolysis (Table II). Since these experiments were carried out in muscles in which lysosomal and calcium-dependent processes were already blocked, we could evaluate the contributions of ATPindependent and ATP-dependent proteolytic systems. With ATP depletion, protein breakdown decreased by $57 \mathrm{U}$ in muscles of acidotic rats and by $37 \mathrm{U}$ in control rats. The resulting fall in protein breakdown represents the fraction of muscle proteolysis that is ATP dependent. This component accounted for most, if not all, of the increase in proteolysis with acidosis. Accordingly, the residual rates of protein degradation in muscles of acidotic and control rats did not differ statistically. Thus, acidosis appears to activate an ATP-dependent proteolytic pathway, but does not affect the residual, ATP-independent, nonlysosomal process.

Changes in mRNA with acidosis. ATP is essential for the predominant cytosolic protein degradation pathway in most cells, including muscle $(9,13,20)$. In this nonlysosomal process, ATP is necessary first for the conjugation of ubiquitin to cell proteins which are then rapidly hydrolyzed by the $26 \mathrm{~S}$ $(1,500 \mathrm{kD})$ ATP-dependent complex containing the proteasome (9-11). To test whether the ATP-dependent process activated by acidosis may involve ubiquitin and the proteasome, we measured the levels of mRNA encoding these components in muscles of normal and acidotic rats. RNA was isolated from the gastrocnemius because this muscle, like the epitrochlearis, is a mixed-fiber muscle and it exhibits similar responses in terms of protein synthesis and degradation as epitrochlearis $(22,26)$. However, being larger, the gastrocnemius contains sufficient RNA for Northern analysis.

In Table III, values of weights and the protein, DNA and

Table I. Blocking Lysosomal and Calcium-dependent Proteolysis Reduces Protein Degradation Similarly in Muscles of Control and Acidotic Rats

\begin{tabular}{|c|c|c|c|}
\hline Additions & Control rats & Acidotic rats & Difference \\
\hline & \multicolumn{3}{|c|}{ nmol tyrosine $/ g$ per $2 h$} \\
\hline None & $142.3 \pm 2.4$ & $166.8 \pm 5.1$ & $24.5 \pm 5.6^{*}$ \\
\hline Inhibitors & $113.2 \pm 4.2$ & $\underline{131.3 \pm 4.1}$ & $\underline{18.1 \pm 5.8^{*}}$ \\
\hline $\begin{array}{l}\text { Lysosomal/calcium- } \\
\text { dependent process }\end{array}$ & $29.1 \pm 4.8$ & $34.5 \pm 6.5$ & $6.4 \pm 8.1$ \\
\hline
\end{tabular}

Values are mean \pm SEM of the rate of protein degradation in incubated epitrochlearis muscles of control and pair-fed rats. Muscles were incubated in KRB (pH 7.4) supplemented with glucose, while the contralateral muscle was maintained at resting length and incubated in calcium-free KRB, supplemented with glucose, insulin, branchedchain amino acids, methylamine, and E-64. * By ANOVA, there was a significant $(P<0.02)$ increase in protein degradation in muscles of acidotic rats and this increase persisted when lysosomal and calcium-dependent proteolysis was inhibited. 
Table II. Evidence for ATP-dependent Protein Degradation in Incubated Muscles of Acidotic Rats

\begin{tabular}{lrrr}
\hline & Control & Acidotic & Increment \\
\hline & \multicolumn{3}{c}{ nmol tyrosin/g per $h$} \\
& & & \\
$\begin{array}{l}\text { Lysosomal/Ca } \\
\quad \text { process }\end{array}$ & $101.6 \pm 4.1$ & $128.3 \pm 5.1$ & $26.7 \pm 7.9$ \\
ATP-depleted & $\underline{64.4 \pm 3.6}$ & $\underline{71.2 \pm 4.4}$ & $\underline{6.8 \pm 6.5}$ \\
ATP-dependent component & $37.2 \pm 4.4$ & $57.1 \pm 5.6$ & $19.9 \pm 7.1$ \\
& & & \\
\hline
\end{tabular}

Values are mean \pm SEM of the rate of protein degradation in incubated epitrochlearis muscles of six control and six pair-fed acidotic rats. To isolate the influence of ATP-dependent proteolysis, the rate of protein degradation in a muscle of a control or acidotic rat was measured and the rate in the contralateral, ATP-depleted muscle was subtracted from it. The lysosomal/calcium-independent process was measured in muscles maintained at resting length and incubated in calcium-free $\mathrm{KRB}$ (pH 7.4), supplemented with glucose, insulin, branched-chain amino acids, methylamine, and E-64. ATP-depleted muscles were incubated in the same media but glucose was removed and 2-deoxyglucose and dinitrophenol were added. By ANOVA, there was a significant $(P<0.02)$ increase in protein degradation in muscles of acidotic rats, but this difference disappears in muscles depleted of ATP.

RNA contents of gastrocnemius muscles are presented. Muscles isolated from acidotic rats weighed less than those of pairfed, control rats, related to a lower protein content, while there was no difference in the DNA content of the muscle. We also found no difference between the RNA contents and the content of the $18 \mathrm{~S}$ and $28 \mathrm{~S}$ RNAs per $\mu \mathrm{g}$ of RNA in muscles of acidotic and control rats were not statistically different. Furthermore, the abundances of GAPDH mRNA (a "house-keeping" gene) in muscles of acidotic and pair-fed rats did not differ significantly when evaluated as the ratios of GAPDH mRNA to 18S RNA and of GAPDH mRNA to 28s RNA (Fig. 1). The density of the GAPDH mRNA signal was measured in the linear range; the density ratio measured after 60 and 30 min of exposure for control muscles was $2.08 \pm 0.04$ and was $2.05 \pm 0.06$ for muscles of acidotic rats.

Blots from muscles of normal and acidotic rats were hybridized with cDNAs for ubiquitin and the $\mathrm{C} 2$ and $\mathrm{C} 3$ subunits of the proteasome. Fig. 2 shows the results of hybridizing with ubiquitin CDNA, the $\mathrm{C} 2$ and $\mathrm{C} 3$ subunit $\mathrm{CDNAs}$ and with the cDNA for a lysosomal enzyme, cathepsin B. When corrected for differences in RNA loading using the GAPDH cDNA, acidosis induced a 2.5- to 4-fold increase in mRNA for ubiquitin in different experiments. As reported previously (15), there are ubiquitin mRNA transcripts in rat muscle of $\sim 2.4$ and $1.3 \mathrm{~kb}$
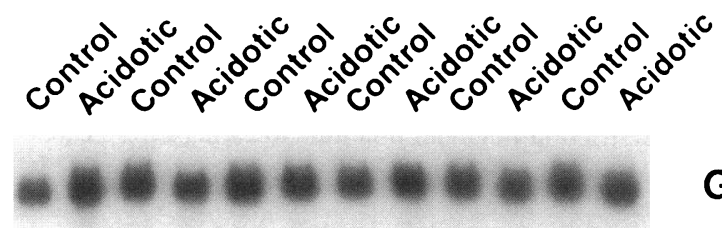

GAPDH

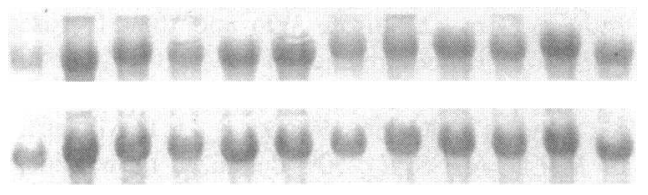

$28 S$

$18 S$

Figure 1. Hybridization signal for GAPDH mRNA from muscles of six pairs of acidotic and pair-fed control rats. Also shown are the density of $18 \mathrm{~S}$ and $28 \mathrm{~S}$ ribosomal RNA as determined by methylene blue staining.

corresponding to the sizes of the polyubiquitin genes in other species $(13,38)$. Both of these transcripts were increased to a similar extent after $\mathrm{NH}_{4} \mathrm{Cl}$ treatment. A third, minor ubiquitin transcript of $\sim 0.9 \mathrm{~kb}$ could also be detected and presumably corresponds to the product of the ubiquitin-extension gene (38).

These findings suggest a specific activation by acidosis of the ATP- ubiquitin-dependent pathway in muscle. Furthermore, in muscles of acidotic rats, mRNA levels for the proteasome subunits which we assayed (C-2 and C-3) rose in parallel with the increase in ubiquitin mRNA. Analysis by laser densitometry (corrected for the level of GAPDH mRNA) revealed that the level of mRNA for the C-2 subunit was 4-fold higher in muscle of five acidotic rats $(P<0.001)$ than in control rats. The mRNA for the C-3 subunit was increased with acidosis ( 2.5 -fold, $P<0.01)$. Similar results were found with two other experiments of five rats in each group. Thus, the catabolic response of muscle to acidosis is characterized by increased expression of components of the ATP-ubiquitin-proteasome-dependent pathway. In contrast, we found no increase in mRNA for the lysosomal protease, cathepsin B, in the muscles of the acidotic rats (Fig. 2).

Since ubiquitin is a heat-shock protein in mammalian cells (39), the increase in its mRNA during acidosis could have occurred as part of the cell's generalized response to stress. To assess whether acidosis induced the heat-shock response in muscle, we measured levels of mRNA for the major cellular heat shock protein, HSP70. As shown in Fig. 3, there was no increase in the mRNA for this stress protein. We also compared ubiquitin mRNA levels in kidneys from acidotic and control rats. In contrast to our findings with muscle, there was no increase in ubiquitin mRNA in kidneys (Fig. 3 ).

Table III. Biochemical Characteristics of Muscles of Control and Pair-fed Acidotic Rats

\begin{tabular}{|c|c|c|c|c|c|c|c|c|}
\hline & $\begin{array}{l}\text { Muscle } \\
\text { weight }\end{array}$ & DNA & Protein & RNA & $18 S$ & $28 \mathrm{~S}$ & GAPDH/18S & GAPDH/28S \\
\hline & $m g$ & mg/muscle & mg/muscle & mg/muscle & \multicolumn{2}{|c|}{ per $10 \mu g R N A$} & & \\
\hline Control & $1034 \pm 19$ & $1110 \pm 28$ & $119 \pm 5$ & $934 \pm 54$ & $0.036 \pm 0.005$ & $0.041 \pm 0.007$ & $1.284 \pm 0.133$ & $1.246 \pm 0.235$ \\
\hline Acidotic & $883 \pm 34^{*}$ & $1161 \pm 55$ & $175 \pm 7^{\ddagger}$ & $892 \pm 35$ & $0.038 \pm 0.003$ & $0.041 \pm 0.0003$ & $1.180 \pm 0.069$ & $1.117 \pm 0.069$ \\
\hline
\end{tabular}

Muscle weight and the content of DNA, protein and RNA are mean \pm SEM of values in gastrocnemius muscles of nine acidotic and six control rats. Measurements of the muscle content of $18 \mathrm{~S}, 28 \mathrm{~S}$, and GAPDH mRNA were obtained from six acidotic and six pair-fed, control rats. ${ }^{*} P$ $<0.005,{ }^{\dagger} P<0.02$ 

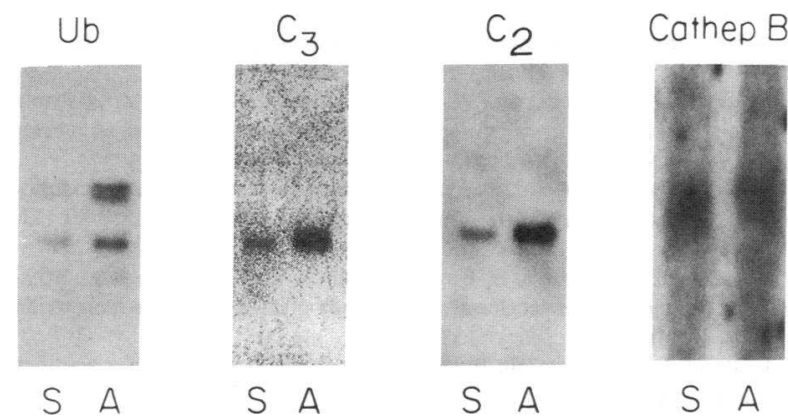

Figure 2. Northern blots to assess abundance of mRNA encoding ubiquitin, C-2 and C1-subunits of the proteasome, and cathepsin B in muscles of acidotic and pair-fed, control rats.

The increase in ubiquitin mRNA in muscle was rapidly reversed after the acidotic rats resumed eating a normal diet. At different times after switching form $\mathrm{NH}_{4} \mathrm{Cl}$ treatment and gavage feeding to $22 \%$ protein pellets and water ad lib., the levels of ubiquitin mRNA in muscle were examined. By $6 \mathrm{~h}$, the ubiquitin mRNA in muscle was lower and it reached control values by $24 \mathrm{~h}$ (Fig. 4 ).

\section{Discussion}

These experiments have provided new insights into the mechanisms by which metabolic acidosis causes negative nitrogen balance and enhanced protein catabolism in skeletal muscle. When muscles from acidotic rats were incubated in vitro, the excessive protein breakdown persisted even when insulin and amino acids plus methylamine were present to suppress the lysosomal process and also when inhibitors of thiol proteases and a calcium-free media were used to block both lysosomal and calcium-activated proteases (Table I). However, this increase in protein degradation was eliminated by blocking ATP production in the muscles (Table II). Thus, acidosis seems to stimulate selectively a nonlysosomal, ATP-dependent proteolytic pathway as has been found to occur in response to fasting and denervation atrophy (15).

Additional evidence for activation of the soluble, ATP-dependent system was the large increase in mRNA for ubiquitin and for subunits of the proteasome in muscle of acidotic rats. These results suggest that acidosis activates a coordinated, proteolytic response, including increased expression of genes that encode ubiquitin and subunits of the proteasome. The protea-

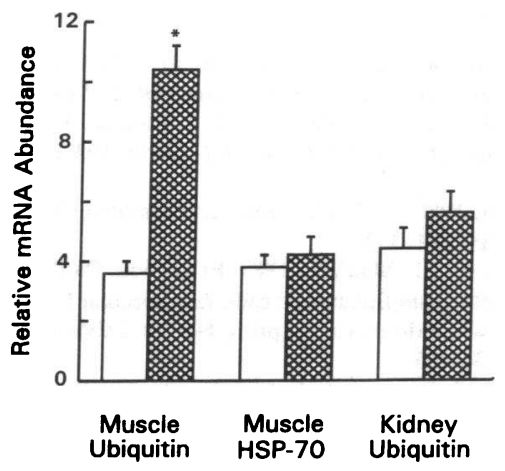

Figure 3. The abundance of mRNA for ubiquitin and HSP70 in gastrocnemius muscles and for ubiquitin in kidneys of five acidotic and five pair-fed, control rats. There was a significant $(P<0.02)$ increase in ubiquitin mRNA but no significant increases in levels of mRNA for HSP70

in muscle nor of ubiquitin in kidneys. These data were corrected for GAPDH mRNA abundance.

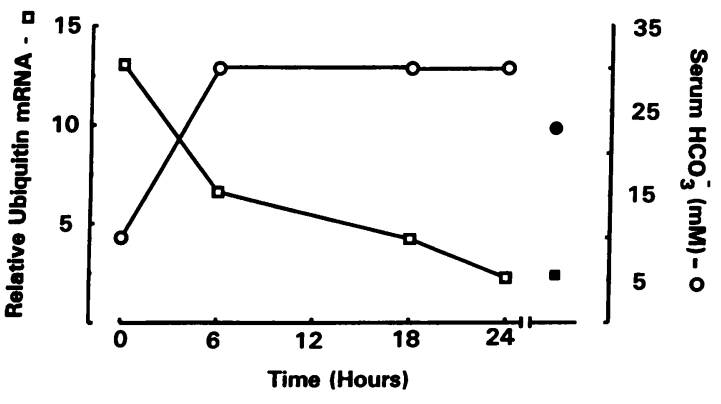

Figure 4. The increase in ubiquitin mRNA in muscles of acidotic rats (circles) decreases rapidly after correction of the plasma bicarbonate concentration (squares). Solid symbols are average values obtained from control, gavage-fed rats. After the $5 \mathrm{~d}$ of gavage-feeding $\mathrm{NH}_{4} \mathrm{Cl}$, the experiment was begun and rats were provided with the standard $22 \%$ protein diet and tap water ad lib. Three rats were sacrificed at each time period after beginning the experiment to measure mRNA abundance (corrected for GAPDH mRNA abundance). After $24 \mathrm{~h}$, ubiquitin mRNA returned to control values $(P<0.05$ vs. initial values by unpaired $t$ test) and serum bicarbonate concentration was 29 $\mathrm{mM}(P<0.05$ vs. initial values $)$ indicating that the metabolic acidosis had been corrected.

some contains multiple proteolytic activities which are essential for degrading proteins conjugated to ubiquitin (9-12). This response appeared to be specific for muscle because ubiquitin mRNA was not increased in kidneys of acidotic rats. Since $\mathrm{mRNA}$ for other heat shock proteins or other proteases (cathepsin B) failed to increase in muscle of acidotic rats, the rise in ubiquitin mRNA does not seem to reflect a generalized stress response (39), but instead appears to be linked to the increased ATP-dependent proteolysis and to the simultaneous rise in proteasome mRNA.

The ATP-ubiquitin-dependent proteolytic system has been most thoroughly characterized in reticulocytes $(9,10,13)$, but it is also present in skeletal muscle (40). This system is generally considered as a constitutive pathway for the rapid degradation of abnormal or short-lived proteins $(9,10,13)$. The present findings and related ones (15), however, suggest that it can be the primary system involved in degrading the bulk of muscle proteins. In muscle, this degradative system appears to be precisely regulated and important in disease states. Recent studies have indicated that the nonlysosomal, ATP-dependent proteolytic system in muscle is activated in other catabolic conditions including starvation (15), cortisol treatment (23) denervation atrophy (15), after endotoxin treatment (Attaix and Goldberg, manuscript in preparation) and cancer cachexia (Baracos et al., manuscript in preparation ). Muscle atrophy is a characteristic feature of these conditions, and in each, evidence for activation of the soluble, ATP-dependent degradative process in muscle was obtained using similar strategies as we have used here. In starvation and denervation atrophy, the total RNA content of the muscles decreased, while the mRNA for the polyubiquitin gene increased (15). Moreover, in response to fasting or denervation, the extent of ubiquitination of cell proteins, seems to be increased especially in the myofibrillar fraction (Wing et al., manuscript in preparation). The present findings resemble earlier observations on fasting in several respects: Medina et al. (15) showed that the rates of proteolysis and levels of mRNA for ubiquitin rapidly returned to control levels upon refeeding the fasted animals. Likewise, when the acidosis 
reversed to normal, the changes in ubiquitin mRNA returned to control levels rapidly. However, our results clearly are not due to fasting, since the animals were gavage-fed. Moreover, the RNA content of muscle was unchanged in acidosis unlike the decrease in RNA content seen in muscles from starved rats (15). Secondly, the enhanced ATP-dependent proteolysis and the rise in ubiquitin mRNA in muscle stimulated by fasting require glucocorticoids $(23)$, as does the increase in protein degradation that is stimulated by acidosis (4). These similar features suggest that acidosis and a number of catabolic conditions activate the same integrated cellular response leading to increased proteolysis. Coordinated regulation of mRNA of ubiquitin and proteasome subunits has also been reported in human leukemic during differentiation $(41,42)$.

The catabolic influence of acidosis is well established in humans, in experimental animals and in incubated myocytes. It may be that more severe acidosis is required to stimulate muscle protein degradation because we did not examine less severe degrees of acidosis. However, it is likely that acidosisstimulated protein degradation may be the explanation for protein wasting in certain diseases such as chronic renal failure. For example, we have found that the muscle protein loss in rats with chronic uremia can be largely explained by acidosis-induced stimulation of protein degradation in muscle (36). In those experiments, simply supplementing the diet with sodium bicarbonate eliminated the increase in muscle protein breakdown. Acidosis also stimulates the oxidation of branchedchain amino acids and can account for accelerated degradation of these amino acids in uremia $(6,43,44)$. Since the adaptive response to dietary protein restriction includes inhibition of amino acid oxidation and protein degradation, the catabolic influence of metabolic acidosis would be especially deleterious in patients who eat poorly because of anorexia or who are being treated with low-protein diets.

In summary, our results show that acidosis activates in muscle, a coordinated program for catabolism of protein and amino acids. These findings strongly suggest (but do not prove) that the accelerated proteolysis is due to greater flux of proteins through the ubiquitin-proteasome-dependent pathway. Other types of experiments will be needed to confirm this conclusion and identify the specific adaptations that trigger the rapid ATP-dependent proteolysis and the associated increases in mRNA for critical components of this pathway.

\section{Acknowledgments}

We thank Dr. M. Martinez and L. Pimentel for assistance in measuring systolic blood pressure and heart rate and Aurora Scott for her assistance in the preparation of this manuscript.

These studies were supported by grants from the National Institutes of Health (NIH) RO1 DK37275, T32 DK07656, and the O'Brien Kidney Research Center, P50 DK45215 to Dr. Mitch; a Merit Award to Dr. England; and awards from the Muscular Dystrophy Association and Hoechst Pharmaceuticals, and NIH RO1 GM46147 to Dr. Goldberg.

\section{References}

1. McSherry, E., and R. C. Morris. 1978. Attainment of normal stature with alkali therapy in infants and children with classic renal tubular acidosis. J. Clin. Invest. 61:509-514.

2. Reaich, D., S. M. Channon, C. M. Scrimgeour, and T. H. J. Goodship. 1992. Ammonium chloride-induced acidosis increases protein breakdown and amino acid oxidation in humans. Am. J. Physiol. 263:E735-E739.
3. Papadoyannakis, N. J., C. J. Stefanides, and M. McGeown. 1984. The effect of the correction of metabolic acidosis on nitrogen and protein balance of patients with chronic renal failure. Am. J. Clin. Nutr. 40:623-627.

4. May, R. C., R. A. Kelly, and W. E. Mitch. 1986. Metabolic acidosis stimulates protein degradation in rat muscle by a glucocorticoid-dependent mechanism. J. Clin. Invest. 77:614-621.

5. Williams, B., E. Layward, and J. Walls. 1991. Skeletal muscle degradation and nitrogen wasting in rats with chronic metabolic acidosis. Clin. Sci. 80:457462.

6. May, R. C., T. Masud, B. Logue, J. Bailey, and B. K. England. 1992. Chronic metabolic acidosis accelerates whole body proteolysis and leucine oxidation in awake rats. Kidney Int. 41:1535-1542.

7. England, B. E., J. Chastain, and W. E. Mitch. 1991. Extracellular acidification changes protein synthesis and degradation in BC3H-1 myocytes. Am. J. Physiol. 260:C277-C282.

8. Kettlehut, I. C., S. S. Wing, and A. L. Goldberg. 1988. Endocrine regulation of protein breakdown in skeletal muscle. Diabetes Metab. Rev. 4:751-772.

9. Hershko, A. and A. Ciechanover. 1992. The ubiquitin system for protein degradation. Annu. Rev. Biochem. 61:761-807.

10. Goldberg, A. L., and K. L. Rock. 1992. Proteolysis, proteasomes and antigen presentation. Nature (Lond.). 357:375-379.

11. Goldberg, A. L. 1992. The mechanism and functions of ATP-dependent proteases in bacterial and animal cells. Eur. J. Biochem. 203:9-23.

12. Rivett, A. J. 1993. Proteasomes: multicatalytic proteinase complexes. Biochem. J. 291:1-10.

13. Rechsteiner, M. 1991. Natural substrates of the ubiquitin proteolytic pathway. Cell. 66:615-618.

14. Furuno, K., M. N. Goodman, and A. L. Goldberg. 1990. Role of different proteolytic systems in the degradation of muscle proteins during denervation atrophy. J. Biol. Chem. 265:8550-8557.

15. Medina, R., S. S. Wing, A. Haas, and A. L. Goldberg. 1991. Activation of the ubiquitin-ATP-dependent proteolytic system in skeletal muscle during fasting and denervation atrophy. Biomed. Biochim. Acta. 50:347-356.

16. Dice, J. F. 1987. Molecular determinants of protein half-lives in eukaryotic cells. FASEB J. 1:349-357.

17. Furuno, K., and A. L. Goldberg. 1986. The activation of protein degradation in muscle by calcium or muscle injury does not involve a lysosomal mechanism. Biochem. J. 237:859-864.

18. Zeman, R. J., T. Kameyama, K. Matsumoto, P. Bernstein, and J. D. Etlinger. 1985. Regulation of protein degradation in muscle by calcium: evidence for enhanced nonlysosomal proteolysis associated with elevated cytosolic calcium. J. Biol. Chem. 260:13619-13624.

19. MacLennon, P. A., A. McArdle, and R. H. T. Edwards. 1991. Effect of calcium on protein turnover of incubated muscles from mdx mice. Am. J. Physiol. 260:E594-E598.

20. Gronostajski, R. M., A. L. Goldberg, and A. B. Pardee. 1984. The role of increased proteolysis in the atrophy and arrest of cell division in fibroblasts following serum deprivation. J. Cell Biol. 121:189-198.

21. Kelly, R. A., J. M. Pfeffer, W. E. Mitch, and T. W. Smith. 1987. Plasma non-esterified fatty acids in the Dahl rat: response to salt loading. Hypertension. 10:1099-1103.

22. Clark, A. S., and W. E. Mitch. 1983. Comparison of protein synthesis and degradation in incubated and perfused muscle. Biochem. J. 212:649-653.

23. Wing, S. S., and A. L. Goldberg. 1993. Glucocorticoids activate the ATPubiquitin-dependent proteolytic system in skeletal muscle during fasting. Am. J. Physiol. 264:E668-E676.

24. Poole, B. and S. Okhuma. 1981. Effect of weak bases on the intralysosomal pH in mouse peritoneal macrophages. J. Cell Biol. 90:665-669.

25. Hanada, K., M. Tamai, T. Adachi, K. Oguma, K. Kashiwagi, S. Ohmura, E. Kominami, T. Towatari, and N. Katunuma. 1983. Characterization of the three new analogs of E-64 and their therapeutic application. In Proteinase Inhibitors: Medical and Biological Aspects. N. Katunuma, editor. Springer-Verlag, Tokyo. 25-36.

26. Ariano, M. A., R. B. Armstrong, and V. R. Edgerton. 1973. Hindlimb muscle fiber populations of five mammals. J. Histochem. Cytochem. 21:51-55.

27. Lowry, O. H., N. J. Rosenbrough, A. L. Farr, and R. J. Randall. 1951. Protein measurement with the Folin phenol reagent. J. Biol. Chem. 193:265275.

28. Labarca, C., and K. Paigen. 1980. A simple, rapid, and sensative DNA assay procedure. Anal. Biochem. 102:344-352.

29. Sambrook, J., E. F. Fritsch, and T. Maniatis. 1989. Extraction, Purification, and Analysis of messenger RNA from Eukaryotic cells. In Molecular Cloning: A Laboratory Manual. N. Irwin, editor. Cold Spring Harbor Laboratory Press, Cold Spring Harbor, NY. 7.3-7.85.

30. Fort, P. W., L. Marty, M. M. Piechaczyk, S. El Sabrouty, C. Dani, P. Jeanteur, and J. M. Blanchard. 1985. Various rat adult tissues express only one major mRNA species from the glyceraldehyde-3-dehydrogenase multigenic family. Nucleic Acids Res. 13:1431-1442.

31. Feinberg, A. P., and B. Vogelstein. 1983. A technique for radiolabeling 
DNA restriction endonuclease fragments to high specific activity. Anal. Biochem. 132:6-13.

32. Chan, S. J., B. San Segundo, M. B. McCormick, and D. F. Steiner. 1986. Nucleotide and predicted amino acid sequences of cloned human and mouse preprocathepsin B cDNAs. Proc. Natl. Acad. Sci. USA. 83:7721-7725.

33. Agell, N., U. Bond, and M. J. Schlesinger. 1988. In vitro proteolytic processing of a diubiquitin and a truncated diubiquitin formed from in vitro-generated mRNAs. Proc. Natl. Acad. Sci. USA. 85:3693-3697.

34. Fujiwara, T., K. Tanaka, A. Kumatori, S. Shin, T. Yoshimura, A. Ichihara, F. Tokunaga, R. Aruga, S. Iwanaga, A. Kakizuka, et al. 1989. Molecular cloning of cDNA for proteasomes (multicatalytic proteinase complexes) from rat liver: primary structure of the largest component (C2). Biochemistry. 28:73327340 .

35. Tokunaga, F., R. Aruga, S. Iwanaga, K. Tanaka, A. Ichihara, T. Takao, and Y. Shimonishi. 1990. The NH2-terminal residues of rat liver proteasome (multicatalytic proteinase complex) subunits, $\mathrm{C} 2, \mathrm{C} 3$ and $\mathrm{C} 8$ are $\mathrm{N}$ alpha-acetylated. FEBS (Fed. Eur. Biochem. Soc.) Lett. 263:373-375.

36. May, R. C., R. A. Kelly, and W. E. Mitch. 1987. Mechanisms for defects in muscle protein metabolism in rats with chronic uremia: the influence of metabolic acidosis. J. Clin. Invest. 79:1099-1103.

37. May, R. C., Y. Hara, R. A. Kelly, K. P. Block, M. G. Buse, and W. E Mitch. 1987. Branched-chain amino acid metabolism in rat muscle: abnorma regulation in acidosis. Am. J. Physiol. 252:E712-E718.
38. Baker, R. T, and P. G. Board. 1991. The human ubiquitin-52 amino acid fusion protein gene shares several structural features with mammalian ribosomal protein genes. Nucleic Acids Res. 19:1035-1040.

39. Fornace, Albert J., Isaac Alamo, M. Christine Hollander, and Etienne Lamoreaux. 1989. Ubiquitin mRNA is a major stress-induced transcript in mammalian cells. Nucleic Acids Res. 17:1215-1230.

40. Fagan, J. M., L. Waxman, and A. L. Goldberg. 1987. Skeletal muscle and liver contain a soluble ATP + ubiquitin-dependent proteolytic system. Biochem J. 243:335-343.

41. Shimbara, N., E. Orino, S. Sone, T. Ogura, M. Takashina, M. Shono, T. Tamura, H. Yasuda, K. Tanaka, and A. Ichihara. 1992. Regulation of gene expression of proteasomes (Multi-protease complexes) during growth and differentiation of human hematopoietic cells. J. Biol. Chem. 267:18100-18109.

42. Shimbara, N., C. Sato, M. Takashina, T. Tanaka, K. Tanaka, and A Ichihara. 1993. Down-regulation of ubiquitin gene expression during differentiation of human leukemia cells. FEBS (Fed. Eur. Biochem. Soc.) Lett. 322:235239.

43. Hara, Y., R. C. May, R. A. Kelly, and W. E. Mitch. 1987. Acidosis, not azotemia, stimulates branched-chain amino acid catabolism in uremic rats. Kidney Int. 32:808-814.

44. Bergstrom, J., A. Alvestrand, and P. Furst. 1990. Plasma and muscle free amino acids in maintenance hemodialysis patients without protein malnutrition. Kidney Int. 38:108-114. 